\title{
AGROECOLOGICAL ASPECTS OF OPTIMIZATION OF THE SYSTEM OF IRRIGATED AGRICULTURE IN THE STEPPE ZONE OF UKRAINE UNDER THE REGIONAL CLIMATE CHANGE
}

\section{Vozhehova R. A.}

\section{INTRODUCTION}

Irrigation plays an important stabilizing role in the food, resource and currency supply of the country, particularly in the years with adverse weather conditions, which increases the importance of meliorated lands due to the global climate change and desertification of the territories. Today, it is one of the main factors and conditions for the intensification of agriculture in the areas with unstable and insufficient natural humidification and even beyond them. However, the associated intensification of agricultural production leads to the emergence of acceptable, maximum allowable and insignificant environmental risks in the large areas, which are the most inhabited in the country ${ }^{1,2}$.

The basis of economically reasonable, sustainable, and long-term agricultural use of meliorated agrosystems is the formation and maintenance of their ecological balance. Therefore, the further development of intensive irrigation requires the determination of acceptable limits of environmental risks in accordance with existing safety requirements and the development of a system of the global management decisions to prevent their manifestation and possible consequences. Irrigated agricultural land in Ukraine exceeds 2.2 million hectares. Among 10.9 billion cubic meters of water used annually in agricultural production, the main share is occupied by irrigation, while

1 Вожегова Р. А., Малярчук М. П., Дробітько А. В. та ін. Наукове обгрунтування напрямів адаптації систем землеробства до кліматичних змін та забезпечення продовольчої безпеки. Наукові основи адаптації систем землеробства до змін клімату в Південному Степу Украӥни: колект. моногр. I за ред. чл.-кор. НААН Вожегової Р. А. Херсон : ОЛДІ-ПЛЮС, 2018. С. 8-39.

${ }^{2}$ Гадзало Я. М., Вожегова Р. А., Коковіхін С. В., Біляєва І. М., Дробітько А. В. Наукове обгрунтування технологій вирощування кукурудзи на зрошуваних землях із урахуванням гідротермічних чинників і змін клімату. Зрошуване землеробство. Херсон, 2020. Вип. 73. С. 21-26. 
the share of water pollution caused by agricultural production is estimated at the level of $16.6 \%$.

The modern development of the agricultural sector in recent years has been based on the use of increasing doses of mineral fertilizers with no applicatiomn of organic ones, as well as the intensification of crop protection by increasing the frequency of spraying with pesticides. Under such conditions, product quality did not always improve. This requires finding ways to improve product quality, to which much attention has been paid in recent years. One of the areas of production of high-quality crop products is the biologization of crop technology 6,7 .

Drip irrigation saves water by $50 \%$ compared to conventional irrigation (sprinkler, by furrows, flood irrigation). Therefore, in organic farming (as in natural cenoses) the soil should be covered with vegetation or plant residues for as long as possible. When growing vegetable plants using organic technologies, the use of the method of hydrosowing is a prospective one. This method of sowing provides obtaining the level of field seeds germination rate as the level of their laboratory germination rate, reduction of sowing rate by one and a half to two times, application of liquid organic fertilizers at the time of sowing, biological plant protection products, microelements, etc. Under such a method, seedlings appear in five or seven days after sowing (in the conventional method - in 12-21 days), earlier than weeds, which provides an increase in yield. Besides, drip irrigation is the most suitable method to produce organic vegetables, which saves irrigation water and

3 Жовтоног О. І., Кириєнко О. І., Шостак І. К. Алгоритм планування зрошення з використанням геоінформаційних технологій для системи точного землеробства. Меліорація і водне господарство. 2004. Вип. 91. С. 33-41.

${ }^{4}$ Зубець М. В. Наукові основи агропромислового виробництва в зоні Степу України. Київ : Аграрна наука, 2004. С 359-363.

5 Жуйков Г. Є., Димов О. М. Нормативи витрат матеріально-технічних ресурсів при вирощуванні основних зернових культур : науково-методичний посібник. Херсон : Айлант, 2004. 20 c.

${ }^{6}$ Іващенко О. О., Рудник-Іващенко О. I. Напрями адаптації аграрного виробництва до змін клімату. Вісник аграрної науки. 2011. № 8. С. 10-12.

7 Коваленко А. М., Коковіхін С. В., Нікішов О. О. Фотосинтетична діяльність та насіннєва продуктивність пшениці озимої залежно від захисту рослин та мікродобрив в умовах Півдня України. Зрошуване землеробство : міжвідомчий тематичний збірник наукових праць. Херсон : Грінь Д.С., 2017. Вип. 67. С. 131-134. 
fertilizers up to $30-40 \%$ or more, provides preservation of soil fertility ${ }^{8,9,10}$.

\section{Directions of rational use of natural and ecological potential of the Steppe zone of Ukraine}

Land is a universal natural resource of agriculture, which is required for the functioning of all industries. It is irreplaceable for other types of resources, and it is the main means of producing crop products on land. The Steppe zone of Ukraine covers an area of 240.2 thousand sq km, which is about $40 \%$ of the territory of the country (603.7 thousand sq $\mathrm{km}$ ). The length in the meridional dimension is $500 \mathrm{~km}$, in the latitudinal $-900 \mathrm{~km}^{11}$.

A characteristic feature of the lowlands, which occupy a significant part of the zone, is the lack of sloping lands, which causes favorable conditions for field crops cultivation. Abiotic soil resources of the Steppe territory were formed on parental rocks of different origin and mechanical composition. More than $80 \%$ of the area is occupied by the most valuable forest species for crop production, on which soils of heavy loamy and light clay composition have been formed. Medium and light loamy soils are located mainly in rivers' valleys, while the first are found locally within the Donetsk and Priazov uplands ${ }^{12}$.

Among other (non-loessy) parental rocks there are alluvial sands (lowlands of the Dnipro river), dense carbonate-free rocks (Donetsk, Prydniprovska and Priazovska uplands), dense carbonate rocks (Steppe part of Crimea, spurs of the Middle Russian Upland, root banks of the Siverskyi Donets, Inhulets, Inhul, Pivdennyi Buh rivers). A feature of

${ }^{8}$ Коковіхін С. В. Моделювання агротехнологічних параметрів системи зрошуваного землеробства з урахуванням показників гідромодулю системи та біологічних потреб культур у короткоротаційних сівозмінах Півдня України. Стан $i$ перспективи впровадження ресурсоощадних, енергозберігаючих технологій вирощування сільськогосподарських культур : матеріали II Міжнародної науково-практичної конференції (15-16 листопада 2017 р.). Дніпро : ДДАЕУ, 2017. С. 60-62.

${ }^{9}$ Сайко В. Ф. Наукові основи землеробства в контексті змін клімату. Вісник аграрної науки. 2008. № 11. С. 5-10.

${ }_{10}$ Тараріко Ю. О. Розробка грунтозахисних ресурсо- та енергозберігаючих систем ведення сільськогосподарського виробництва 3 використанням комп’ютерного програмного комплексу. Київ: Нора-Друк, 2002. 122 с.

11 Полупан М. І., Соловей В. Б., Величко В. А. Класифікація грунтів України. Київ : Аграрна наука, 2005. С. 144-156.

12 Третяк А. М., Бобміндра Д. І. Земельні ресурси України та їх використання. Київ, 2003. 144 с. 
soils formed on dense parental rocks is gravel, which significantly reduces their potential fertility ${ }^{13}$.

To zone the Steppe area by moisture supply resources, nature of soil formation and soil fertility a relative parameter - hydrothermal coefficient of Selianinov (HTC) - is used, which expresses the ratio between precipitation for the period with an average daily air temperature above $10^{\circ} \mathrm{C}$ and the sum of the temperatures for this period, multiplied by $10^{14}$.

Each soil-ecological zone of the Steppe is characterized by a certain type of soil, which differs in terms of agronomic quality, and hence potential (natural) productivity. Rational use of land resources in adaptive crop production is possible only with deep knowledge and consideration of soil fertility. Three main types of soils have been formed on the territory of the Steppe: common chornozems; southern chornozems; chestnut soils and solonetz soils ${ }^{15,16}$.

The allocation of geographical zones and subzones of the Steppe territory is based on the types of natural conditions, and the main criterion is the typical composition of the soil cover. In the structure of land resources of the Steppe, the largest share is occupied by chornozems $(80.3 \%$ as a part of agricultural lands and $84.2 \%$ as a part of arable lands), and chestnut (respectively, 7.4 and $8.0 \%$ ) soils. Meadowchernozem, meadow-chestnut, meadow solonetz soils are also quite common. According to the generally determined moisture resources and the corresponding properties, chernozem soils are divided into two types - common chernozems and southern chernozems. Common chernozems are formed in the conditions of the Northern Steppe zone with HTC V-IX $=0.68-0.89$, are characterized by the most favorable water-physical properties, the highest moisture supply, and hence the highest natural productivity (Table 1). The humus content is $3.8-5.5 \%$.

13 Ушкаренко В. О., Андрусенко І. І., Пилипенко Ю. В. Екологізація землеробства і природокористування в Степу України. Таврійський науковий вісник. Херсон : Айлант, 2005. Вип. 38. С. 168-175.

14 Ушкаренко В. О., Вожегова Р. А., Голобородько С. П., Коковіхін С. В. Статистичний аналіз результатів польових дослідів у землеробстві : монографія. Херсон : Айлант, 2013. 403 с.

15 Ничипорович А. А. Фотосинтетическая деятельность растений в посевах. Москва : АН СССР, 1961. 133 с.

${ }^{16}$ Агрокліматичні ресурси Півдня України та їх раціональне використання : монографія / Лимар А. О., Лимар В. А., Коковіхін С. В. Домарацький Є. О. Херсон : Грінь Д.С., 2015. 246 с. 
Table 1

Parameters of natural fertility potential of the Steppe soils

\begin{tabular}{|c|c|c|c|c|c|c|c|}
\hline \multirow{2}{*}{$\begin{array}{l}\text { Physical } \\
\text { clay, \% }\end{array}$} & \multicolumn{2}{|c|}{ Humus content } & \multicolumn{3}{|c|}{$\begin{array}{l}\text { HTC be the periods } \\
\text { of the growing season }\end{array}$} & \multicolumn{2}{|c|}{ Precipitation XI-III } \\
\hline & $\begin{array}{c}\% \text { in } \\
0-30 \mathrm{~cm}\end{array}$ & $\begin{array}{l}\text { t/ha } \\
\text { in the } \\
\text { profile }\end{array}$ & V-VII & VIII-IX & V-IX & $\mathbf{m m}$ & $\begin{array}{c}\% \\
\text { efficiency }\end{array}$ \\
\hline \multicolumn{8}{|c|}{ Common chernozems } \\
\hline $36-40$ & $3.3-3.8$ & 325 & 0.95 & 0.77 & 0.88 & $140-160$ & 52 \\
\hline $41-45$ & $2.8-3.1$ & 240 & 0.77 & 0.60 & 0.70 & $140-160$ & 58 \\
\hline $56-60$ & $5.3-5.5$ & 500 & 0.95 & 0.68 & 0.84 & $120-140$ & 65 \\
\hline \multicolumn{8}{|c|}{ Southern chernozems } \\
\hline $36-40$ & $2.1-2.3$ & 180 & 0.77 & 0.45 & 0.64 & $120-140$ & 80 \\
\hline $51-55$ & $3.0-3.2$ & 210 & 0.77 & 0.45 & 0.64 & $120-140$ & 30 \\
\hline \multicolumn{8}{|c|}{ Dark-chestnut soil } \\
\hline $41-45$ & $2.0-2.3$ & 160 & 0.69 & 0.45 & 0.59 & 120 & 72 \\
\hline $61-65$ & $3.1-3.3$ & 210 & 0.75 & 0.44 & 0.63 & 140 & 72 \\
\hline \multicolumn{8}{|c|}{ Chestnut soil } \\
\hline $41-45$ & $1.6-1.8$ & 95 & 0.54 & 0.45 & 0.50 & $120-140$ & 72 \\
\hline $61-65$ & $2.2-2.4$ & 160 & 0.53 & 0.45 & 0.50 & $120-140$ & 72 \\
\hline
\end{tabular}

Southern chornozems are common in the Southern Steppe Zone with $\mathrm{HTC}=0.61-0.67$ and are represented by one weakly humus subtype, the humus content is $2.7-4.0 \%$. A feature of the southern chornozems is the flatness of the distribution area, which contributes to their crop use. Chornozem soils are characterized by the highest fertility potential in the world.

Chestnut soils are formed in the Dry Steppe zone with HTC $=0.45-0.60$. According to the natural features of quality, these soils are divided into two subtypes: dark chestnut low-humus (2.3-3.3\% of humus in the arable layer) and alkaline (solonetz) chestnut very low-humus (1.6-2.4\%).

Chestnut solonetz soils in the complex with solonetz soils are distributed in a very dry subzone of the Prysyvasko-Prychornomorsky region with HTC during the growing season of spring crops (V-IX) averaged to $0.45-0.51$. The profile of chestnut solonetz soils clearly shows signs of alkalinity that together with the aridity of the climate significantly worsens their conditions for field crops cultivation.

Among all types of soils in Ukraine, the most common are chornozems, which occupy about $60 \%$ of all land in the country and about $30 \%$ of their world area. Chornozems are the national wealth of Ukraine, a powerful source of renewable life energy. 
Almost all the territory of the Steppe receives enough heat for the cultivation of most temperate crops (Table 2).

Table 2

Climatic parameters of soil-ecological territories of the Steppe

\begin{tabular}{|c|c|c|c|c|c|}
\hline \multicolumn{4}{|c|}{ Growing season } & \multirow{3}{*}{$\begin{array}{c}\text { Temperature } \\
\text { in January, } \\
{ }^{\circ} \mathrm{C}\end{array}$} & \multirow{3}{*}{$\begin{array}{c}\text { Annual } \\
\text { precipitation, } \\
\text { mm }\end{array}$} \\
\hline \multicolumn{3}{|c|}{ V-IX } & XI-III & & \\
\hline$\underset{t>10^{\circ} \mathrm{C}}{\text { Sum }}$ & HTC & $\begin{array}{c}\text { Precipitation, } \\
\text { mm }\end{array}$ & $\begin{array}{c}\text { Precipitation, } \\
\text { mm }\end{array}$ & & \\
\hline \multicolumn{6}{|c|}{ Northern Steppe Zone } \\
\hline $\begin{array}{c}2750- \\
2950 \\
\end{array}$ & $\begin{array}{c}0.68- \\
0.89\end{array}$ & 200-265 & $120-210$ & $-(7.9-0.7)$ & $400-520$ \\
\hline \multicolumn{6}{|c|}{ Steppe Northern-Central insufficiently humidified subzone } \\
\hline $\begin{array}{c}2750- \\
2800\end{array}$ & $\begin{array}{l}0.83- \\
0.89\end{array}$ & 230-265 & $120-210$ & $-(7.9-3.3)$ & $440-520$ \\
\hline \multicolumn{6}{|c|}{ Steppe Southern-Central moderately arid subzone } \\
\hline $\begin{array}{c}2800- \\
2900 \\
\end{array}$ & $\begin{array}{c}0.76- \\
0.82 \\
\end{array}$ & $215-240$ & $120-210$ & $-(7.9-2.0)$ & $400-500$ \\
\hline \multicolumn{6}{|c|}{ Steppe Southern-Central arid subzone } \\
\hline $\begin{array}{c}2900- \\
2950 \\
\end{array}$ & $\begin{array}{c}0.68- \\
0.75 \\
\end{array}$ & $200-225$ & $120-210$ & $-(5.5-0.7)$ & $400-460$ \\
\hline \multicolumn{6}{|c|}{ Southern Steppe Zone } \\
\hline $\begin{array}{c}2950- \\
3050\end{array}$ & $\begin{array}{c}0.61- \\
0.67\end{array}$ & $180-200$ & $120-160$ & $-(4.4-0.7)$ & $370-430$ \\
\hline \multicolumn{6}{|c|}{ Dry Steppe Zone } \\
\hline $\begin{array}{c}3000- \\
3050\end{array}$ & $\begin{array}{c}0.45- \\
0.60\end{array}$ & $140-185$ & $120-140$ & $-(4.4-2.0)$ & $310-390$ \\
\hline \multicolumn{6}{|c|}{ Dry-Steppe dry subzone } \\
\hline $\begin{array}{c}3000- \\
3050 \\
\end{array}$ & $\begin{array}{c}0.52- \\
0.60 \\
\end{array}$ & $155-185$ & $120-140$ & $-(4.4-2.0)$ & $340-390$ \\
\hline \multicolumn{6}{|c|}{ Dry-Steppe extremely dry subzone } \\
\hline $\begin{array}{c}3000- \\
3050\end{array}$ & $\begin{array}{c}0.45- \\
0.51\end{array}$ & $140-165$ & $120-140$ & $-(3.2-2.0)$ & $310-345$ \\
\hline
\end{tabular}

Zoning by soil and economic status provides an opportunity to differentiate and efficiently use the resources of the Steppe lands by adaptive crop production and to develop and implement appropriate systems to protect and improve soil fertility. For this purpose, it is necessary to analyze in detail the soil and ecological resources of the Steppe zone for the formation of agrobiologically sound technologies for cultivating cereals and legumes.

The general state strategy for the development of the agricultural sector of Ukraine should be the priority of sustainable development of 
the crop production sector as a basis that is determined by the irreplaceability of agricultural products and food in human life and society, its exceptional social significance.

Crop production in Ukraine has the age-old fundamental scientific and practical achievements of efficient management in different soil and climatic conditions, the history of the industry has formed the status of Ukraine primarily as an agrarian country. Agriculture of Ukraine with its basic sectoral components is a system-forming in the national economy, it forms the factors of preserving the sovereignty of the country: food, economic, environmental and energy security of the state, ensures the development of many sectors of the national economy.

Crop production in the agrarian sector has its objective advantages of natural resource potential, able to provide production potential that far exceeds the needs of the domestic market, is an industry that at this stage can strategically become (within certain limits) the locomotive of the economic development, give impetus to investment, technological and social rise in the country.

The strategy of the Steppe crop production development for the future period should be directed on the formation of an efficient, resourcesaving, environmentally friendly, socially oriented, science-intensive sector of the state economy, capable to meet the demands of the domestic market and keep up leading export positions in crop products.

Obtaining high and sustainable crop yields is based on the highly efficient use of soil and climatic resources. In agricultural production, in contrast to other sectors of the economy, these conditions are the most important constituents, which are irreplaceable in the process of the crop products production.

At the same time, natural resources differ from conventional productive means by the ability to natural restoration of their properties that had been lost completely or partially in the process of their use. The degree of the property's restoration of some types of the resources (solar radiation, heat, etc.) depends little on the nature of production, and the degree of restoration of others (agrophysical structure of soil, nutrient reserves, and productive moisture in the soil) are determined by the intensity of their use in the process of crops cultivation.

Natural resources that are directly regulated are subject to management due to the main factors of intensification of modern agriculture - chemicalization (fertilization, gypsum application, application of herbicides), improvement in the structure of sown areas, tillage, and replenishment of soil moisture by irrigation. Based on these 
factors, soil fertility increases, water supply improves, and the best conditions are created for obtaining high yields of crops.

A distinctive feature of intensive agriculture is the increasing dependence on the plant life resources. The degree of their use is determined by the nature of the object (crop) and the interaction between it and plant life resources in the process of crop formation. The task of obtaining sustainable yields is mainly reduced to approaching as far as possible environmental conditions meeting the requirements of plants.

The most important condition for further improvement in the efficiency of agriculture is the correct evaluation and investigation of natural resources of the region, based on an in-depth analysis of the dependence of crop yields on soil and climatic peculiarities. The constantly growing need to consider soil and climatic factors is due to the strengthening of their impact on the result. Comparison of the data of the real level of agroclimatic resources with the plants' requirements allows to highly accurately determine the factors that limit the obtaining of high yields.

It is important to point out that in the systems of intensive irrigated agriculture such factors as heat, light, moisture, nutrients are used with a higher efficiency. Under an insufficient level of agrotechnology, soil and climatic resources are spent to a greater extent not on the accumulation of biological mass, but on physiological processes, which leads to the loss of accumulated organic matter.

For a rational investigation of soil and climatic resources, a more precise definition of the primary bioclimatic constants for each crop is needed. Bioclimatic classification of plants allows to correctly evaluate the potential climatic capacities of the region. And this, in its turn, opens opportunities for the development of rational crop rotations, selection of such crops, hybrids, varieties that will ensure the maximum use of the entire growing season, creating a high photosynthetic potential of crops and the highest yield per the unit of area.

The main and most important bioclimatic characteristics of plants include the duration of the growing season, the requirements for thermal factors, the degree of efficient water use, the features of the photoperiodic reaction.

The bioclimatic parameters of plants are influenced not only by variations in weather conditions, but also by varietal composition. The latter is important because inter-varietal differences can be quite significant, and the choice of variety often plays a crucial role in 
determination of the possibilities in the cultivation of a particular crop or group of crops.

Despite regional differences, solar radiation provides the required amount of energy to all the crops cultivated in southern Ukraine, even with and excess. It is determined that the energy demand of plants practically does not depend on the conditions of moisture supply and the level of mineral nutrition. That is why it is the basis for calculating the maximum possible yield at a given PAR adsorption coefficient, which is the starting point for programming. Knowledge of the amount of photosynthetic active radiation income during the potential growing season or during the time that makes up any other part of it, we can set the task of rational accumulation of this energy by cultivated plants. And then based on such an index it is possible to determine the potential yield of the main crop or intercrop, variety.

Potential yield is determined by the biological capabilities of the plant, the income and absorption of photosynthetic active radiation by plants. It is possible provided that the requirements of plants in heat and material factors of life are completely met, i.e., when the level of agrotechnology and melioration will allow to bring the coefficient of PAR absorption to the maximum level.

High yields of cereals and legumes could be obtained only under favorable conditions: a high level of agrotechnology, sufficient supply of crops with nutrients, water, optimal plant density, the corresponding yielding properties of varieties. To obtain high yields, it is necessary that every unit of PAR energy received during the growing season, and each percent of its use for photosynthesis and accumulation in the crop, the plants received about $750 \mathrm{~m}^{3} /$ ha of water available for transpiration, $25-30 \mathrm{~kg} / \mathrm{ha}$ available nitrogen, and a total of $150 \mathrm{~kg} / \mathrm{ha}$ of mineral nutrition in the optimal proportions.

Besides the income of PAR, plants are significantly affected by the duration of day. It was found that some plants develop faster in long day, and others - in short one. The day duration in the time of spring sowing approaches 14 hours, in June it reaches 17 hours, and then begins to decrease to 15 hours by mid-August and to 11.5 hours by the end of September. Therefore, at spring terms of sowing, the conditions are most favorable for growth and development of plants of a long day, and at summer crops - for short day plants. The factor of the day duration is especially important at planning the cultivation of intercrops and the selection of components of the agrophytocenosis. 
Thermal resources of the Steppe zone of Ukraine are one of the main factors in the differentiation of agricultural production and agricultural productivity. The South of Ukraine is characterized by enough heat. The duration of the warm period averages to 280-290 days, the cold period respectively, $75-85$ days. Assessing heat supply, it is important firstly to determine the number of days with certain temperature transitions during which the vegetation of different crops is possible, as well as the sum of active temperatures, which characterizes the compliance with heat requirements of individual crops (Table 3).

Table 3

Thermal resources of the South of Ukraine [16]

\begin{tabular}{|c|c|c|c|c|c|c|}
\hline \multirow{2}{*}{$\begin{array}{c}\text { Region, } \\
\text { (oblast) }\end{array}$} & \multicolumn{2}{|c|}{$\begin{array}{c}\text { The number of days with the } \\
\text { temperatures above }\end{array}$} & \multicolumn{2}{|c|}{$\begin{array}{c}\text { Average dates of air } \\
\text { frosts, day/month }\end{array}$} & $\begin{array}{c}\text { Sum of } \\
\text { active } \\
\text { temperatu } \\
\text { res. }\end{array}{ }^{\circ} \mathbf{C}$ \\
\hline Zaporizhzhia & $251-269$ & $207-220$ & $167-180$ & $14 / 04$ & $15 / 10$ & $2940-3450$ \\
\hline Mykolaiv & $281-315$ & $226-242$ & $178-190$ & $25 / 04$ & $10 / 10$ & $3080-3600$ \\
\hline Odesa & $259-272$ & $212-224$ & $172-183$ & $9 / 04$ & $27 / 10$ & $3020-3480$ \\
\hline Kherson & $257-306$ & $212-245$ & $169-192$ & $13 / 04$ & $24 / 10$ & $2880-3610$ \\
\hline AR Crimea & $265-290$ & $218-232$ & $177-187$ & $15 / 04$ & $16 / 10$ & $3260-3500$ \\
\hline
\end{tabular}

For most crops cultivated in the South of Ukraine, the period when the average daily temperature exceeds $5^{\circ} \mathrm{C}$ above zero is the most important, and for the warm-season crops $-10^{\circ} \mathrm{C}$ above zero. The sums of positive temperatures above $5^{\circ} \mathrm{C}$ during the vegetation period in the South of Ukraine are $3430^{\circ} \mathrm{C}$, above $10^{\circ} \mathrm{C}-3075^{\circ} \mathrm{C}$, above $15^{\circ} \mathrm{C}-$ $2540^{\circ} \mathrm{C}$. The average annual air temperature in the South of Ukraine ranges within 8 to $10.8^{\circ} \mathrm{C}$. The average temperature of the warmest month (July) fluctuates from 20.6 to $23.9^{\circ} \mathrm{C}$, and of the coldest one (January) - from 0.6 to $5.8^{\circ} \mathrm{C}$ below zero.

\section{Adaptation of crops cultivation technologies on the irrigated lands of the Steppe zone of Ukraine}

The growing season in the southern part of the region begins on March 20-31, in the north - on April 1-5. The end of the growing season is on November 15-25 in the southwestern part and on November 1-15 in the northeastern part. Comparison of the actual heat resources in the South of Ukraine with the stated requirements of crops indicates the full 
satisfaction of the requirements of warm-season crops: rice, melons, vegetables, as well as the feasibility of the repeated crops after the cultivation of some crops.

At the cultivation of some crops, only a part of the growing season is used, and some energy reserve remains, which could be used for the cultivation of intercrops. The residual heat resources and the growing season after harvesting some crops or mixed crops and the possibility of their use for the cultivation of intercrops are determined in the Table 4.

Table 4

Frost-free period duration and residual heat after harvesting some crops

\begin{tabular}{|c|c|c|c|c|}
\hline \multirow{2}{*}{ Crop } & \multicolumn{2}{|c|}{ Harvesting period } & Days to \\
\cline { 2 - 3 } frost start & vegetation stage & $\begin{array}{c}\text { Sum of active } \\
\text { demperatures, } \\
{ }^{\circ} \mathbf{C}\end{array}$ \\
\hline Winter barley & Start of earing & $30 / 05-05 / 06$ & $130-135$ & $2300-2850$ \\
\hline Winter wheat & Full ripeness & $05 / 07-10 / 07$ & $90-100$ & $1600-2150$ \\
\hline Spring barley & Start of earing & $10 / 06-15 / 06$ & $120-125$ & $2100-2700$ \\
\hline Corn & Milk-wax ripeness & $05 / 08-15 / 08$ & $60-70$ & $900-1350$ \\
\hline Peas & Technical ripeness & $10 / 07-15 / 06$ & $120-125$ & $2100-2400$ \\
\hline
\end{tabular}

At the crops cultivation in the postharvest period (after harvesting winter wheat), their ability to reduce the duration of the growing season due to higher temperatures in the initial period of growth and the typical photoperiodic reaction should be taken into account.

Long-day crops in the post-harvest crops are characterized by more intensive growth. Although the stages of development are delayed, the ability to increase the vegetative mass increases. At the same time, the demand for heat decreases by $200-300^{\circ} \mathrm{C}$ (in total). All these facts determine the favorable conditions for post-harvest cultivation of crops.

The duration of plants' vegetation and the amount of heat required are determined in the Table 5 based on the generalization of the materials of our studies. 
Growing season duration and the demands for heat at the cultivation of field crops in the period after harvesting

\begin{tabular}{|c|c|c|c|}
\hline Crop & $\begin{array}{c}\text { Growing stage } \\
\text { at harvesting }\end{array}$ & $\begin{array}{c}\text { Growing } \\
\text { season, days }\end{array}$ & $\begin{array}{c}\text { Minimum sum } \\
\text { of active } \\
\text { temperatures, } \\
\text { 'C }\end{array}$ \\
\hline $\begin{array}{c}\text { Early ripening varieties of } \\
\text { millet, buckwheat, peas, mustard }\end{array}$ & Full ripeness & $70-85$ & $1100-1200$ \\
\hline $\begin{array}{c}\text { Middle ripening varieties of } \\
\text { these crops, Early ripening } \\
\text { hybrids of corn }\end{array}$ & Full ripeness & $95-125$ & $1550-2100$ \\
\hline $\begin{array}{c}\text { Barley, millet, ryegrass, peas, } \\
\text { soybeans, vetch, buckwheat }\end{array}$ & Flowering & $60-65$ & $950-1050$ \\
\hline $\begin{array}{c}\text { Corn, sorghum, } \\
\text { Sudanese grass, millet }\end{array}$ & Full ripeness & $60-90$ & $1400-1600$ \\
\hline
\end{tabular}

The list of the crops cultivated in the South of Ukraine is remarkably diverse. Thermal resources here provide the opportunity to obtain high yields, including late-ripening crops (corn, millet, soybeans) not only in the main sowing period, but also in the postharvest period. It is important to avoid large gaps between harvesting the previous main crop and sowing the intercrop. Thus, during the ten-day break of these terms, $200-250^{\circ} \mathrm{C}$ of active temperatures are lost, which is equivalent to the loss of the future grain yield of $0.7-1.2 \mathrm{t} / \mathrm{ha}$.

The south of Ukraine is extremely limited in moisture resources during this period, so the cultivation of intercrops is effective only under irrigation.

Moisture supply conditions, as an important factor in plant life, often limit the obtaining of high and sustainable yields. The main peculiarity of this factor is that some of its values (soil moisture, air humidity in the crop) can be changed with a set of agronomic and melioration measures and thus improve the conditions for crops cultivation.

The values included in the complex of moisture supply conditions characterize the regime of humidification of the surface layer of the atmosphere and soil. These include absolute and relative humidity, its deficit, the characteristics of the regime of precipitation and moisture storage in the soil, complex indices of heat and moisture supply. These values are closely interrelated.

The main source of moisture on the earth's surface is precipitation, which falls in the drip-liquid or solid phase and possesses a layer of 
water with a thickness of a certain number of millimeters. The precipitation regime is characterized by such indices as type, quantity, intensity, number of days with precipitation of different amounts.

Among all the meteorological figures, precipitation is one of the most variable in space and time. A distinctive feature of the spatial distribution of precipitation is the considerable diversity of its income, especially in the form of showers, which in some locations reaches and sometimes exceeds the absolute monthly maximum. For example, in Mykolayiv on May 30, $1955,190 \mathrm{~mm}$ of rain fell in one downpour. The nature of precipitation depends on both the season and the physical and geographical features of the regions themselves. The greatest spatial variability is usual in coastal areas. For the temporary variability of monthly precipitation amounts, the characteristic features are significant fluctuations over the years - they can be several times less or greater than the long-term norm. The precipitation amount in the South of Ukraine is characterized by the lowest values compared to other climatic zones.

The postharvest period is characterized by a lack of moisture. This is due to summer droughts, low rainfall (less than $50 \%$ of the amount for the entire growing season), high evaporation and significant depletion of soil moisture in the previous period.

If the average long-term moisture storage in the Steppe zone during the sowing of late crops is $25-35 \mathrm{~mm}$ in the arable layer of soil, or 100$150 \mathrm{~mm}$ in the meter layer, under the timely conduction of spring field works and optimal sowing dates, normal seedlings appear. In the postharvest period, soil moisture storage decreases to $5-10 \mathrm{~mm}$ in the arable layer and to $20-50 \mathrm{~mm}$ in the meter layer. This amount of moisture is insufficient for seed germination. It is worth remembering that the reduction of productive moisture in the arable layer to $20 \mathrm{~mm}$ is the beginning of the droughty period, and up to $10 \mathrm{~mm}$ - the beginning of the dry period. At the same time, we pay attention to the significant increase in precipitation in the South of Ukraine in recent years, which confirms our analysis by the meteorological stations of Kherson oblast.

Estimated yields of field crops based on precipitation data are given in the Table 6. According to them, it is possible to approximately determine the productivity of crops in the Southern Steppe of Ukraine. 
Table 6

Theoretical figures of field crops yields estimated by precipitation amounts, $\mathbf{t} / \mathbf{h a}$

\begin{tabular}{|c|c|c|}
\hline \multirow{2}{*}{ Crops } & \multicolumn{2}{|c|}{ Terms of sowing } \\
\cline { 2 - 3 } & spring & postharvest \\
\hline Early cereals: - for grain & $2.0-2.6$ & - \\
- for green mass & $22.5-32.5$ & $15.0-20.0$ \\
\hline Late cereals: - for grain & $3.0-3.6$ & $1.6-2.2$ \\
- for green mass & $37.5-45.0$ & $20.0-27.5$ \\
\hline
\end{tabular}

In the conditions of irrigated agriculture, the most favorable water regime for plants is created. However, the rational use of available water resources is important. In this regard, it is necessary to know the amount of moisture deficit in different by the moisture supply years. Therefore, the estimation of moisture supply should be defined not by precipitation, but by the deficit of water use, which is a complex index of the water balance of the root layer of the soil, which determines the demand of plants for additional humidification.

This is explained by the fact that the figure of water use involves not only precipitation of the growing season, but also soil moisture storage, the presence of which, especially at the beginning of the growing season, depends mainly on the precipitation of the previous period. The role of soil moisture storage is significant, it can account for $40-50 \%$ of total water use. A certain amount of moisture is saved owing to the shallow layer of groundwater (up to $3 \mathrm{~m}$ ) that takes part in the water use of plants. In moderately dry years, which correspond to the years with $25 \%$ of water supply, and in moderately wet years, which are equivalent to $75 \%$ of water supply, the largest deficit of the water use of cereals is observed in Zaporizhzhia, Mykolaiv, Kherson oblasts and the Autonomous Republic of Crimea. In the conditions of the South of Ukraine, there is a great disproportion that is expressed in the abundance of energy and thermal resources under the deficit of precipitation. Therefore, irrigation is of a great efficiency here.

The most important characteristics of the extremity in the conditions of moisture supply in the southern regions of Ukraine are the indices of intensity and recurrence of droughts: duration and recurrence of rainless periods, duration, recurrence and coverage of droughts, number of days with dry winds and their intensity.

In the Steppe zone of Ukraine, rainless periods, the duration of which exceeds 1-2 months, are observed each year. Rainless periods lasting 
10-20 days occur two or three times a year during the growing season. The first days of rainless periods do not pose a danger to the development of crops. From the tenth day, the lack of rain has a negative effect on the condition of plants, especially in the stages of earing and flowering, when the demand for moisture is greatest. Starting from the tenth day of no rain, the following days are considered droughty. Therefore, the number of dry days in the rainless period will be by 9 less than the total number of days in the period. In the Steppe zone, the number of droughty days increases from 50 on the border with the Forest-Steppe zone - to 90-94 in the coastal strip. Rainless periods are the reason for droughts and dry winds.

The recurrence of spring droughts in the Southern Steppe regions of Ukraine is about $40 \%$, summer droughts reach 80-90\%, and autumn only $20 \%$. The probability of droughts covering the entire summer period varies from the North to the South from 20 to $50 \%$. In the South of Kherson oblast, in the coastal strip, their probability is $50-60 \%$. The days when the relative humidity is less than $30 \%$ are considered dry. They are most often observed in the southern and eastern parts of the Steppe zone. Dry days are observed mainly in the warm period of the year. In winter, the number of such days is insignificant. In the spring, their number increases and in April-May in some places reaches 7-9 days. In the spring, the combination of low humidity (less than $30 \%$ ) with low temperatures (cold drought) causes great damage to winter crops. Such conditions are especially harmful in late April-early May when winter plants are the formation of spikelet and flowers in spikelet. Under the influence of such conditions, the number of grains per ear could be significantly reduced, which, all in all, significantly affects the yield.

July and August are the driest months of the year. Intense air warming and a decrease in precipitation lead to an increase in the number of dry days to 9-12 and a decrease in humidity below $30 \%$ in the areas, which are far from the seacoast. The greatest number of the days with dry winds during the year is observed in Kherson oblast - from 16 to 22, the lowest - in Odesa - from 5 to 15 days; in another part of the region, excepting the coastal areas, the number of the days with dry winds is from 11 to 20 .

The southern region is characterized by a significant duration of the days with the temperatures above $30^{\circ} \mathrm{C}$ (25-30 days) and relative humidity below $30 \%$ (30-35 days). These weather indices in the combination with winds of speed more than $5 \mathrm{~m} / \mathrm{sec}$ are the constituents of the dry wind period. Such winds occur in all the months of the warm 
period with the greatest frequency in August. In the warm period of the year, the most significant areas with an increased number of days with dry winds are observed here. The most active of them appear in Mykolayiv and Kherson oblasts, where the annual recurrence of dry winds exceeds 15 days. In Odesa oblast, the average number of days with dry winds per year is 7 . In some years, dry winds in the Southern Steppe last from 36 to 50 days.

The initial sign of damage to cereals from dry wind is wilting, and then twisting of the leaves. Further yellowing or drying of leaves in a green form and whitening of spikes of an ear is observed. Such symptoms are irreversible. The greatest damage caused by dry winds is inflicted during the period of filling and ripening of grain. When combined with drought in the air, which causes dry winds for 3-5 days, there is a decrease in grain weight by $40 \%$ or more.

The main reason for wind erosion is continuous plowing of the soil with moldboard plows. Increasing plowing of the territory leads to the increase in the frequency of wind erosion. Irrigation is an important factor of the reduction of the negative impact of dry winds and sandstorms. Under the influence of irrigation, their probability decreases, because the humidity of the arable layer of the soil increases and the microclimate of crops improves. Irrigation is especially effective on hot, dry days. Due to the increased evaporation of moisture from the soil surface and transpiration of plants, the air temperature in crops decreases by $4-6^{\circ} \mathrm{C}$, and the relative humidity increases by $20-40 \%$.

The main task of crop production and agriculture in Ukraine was and remains the creation of the necessary conditions for sustainable agriculture based on intensive use of natural and agronomic resources, preservation and increase of soil fertility. In the implementation of this task, the techniques that promote efficient land use and ensure the ecological balance of the environment are important.

The role of the time factor in these methods has an exceptional significance. Regarding agrobiocenoses, it acts as a set of individual processes, alternating in terms of their implementation. Management of temporal indices (duration of agrophytocenoses and their elements lifetime; alternation in time of the stages of organogenesis, stages of plant development and other biological processes, measures of cultivation technology) is combined in crop rotation, which is the basis of the systems of agriculture.

The invaluable natural wealth of the Steppe of Ukraine is fertile soils. With sufficient light and heat in the region, they can be used effectively 
only based on regulating fertility factors by the means of irrigation. Deterioration of the ecological condition of the irrigated lands in the agriculture of Ukraine is caused by the reduction of the area of crops that restore fertility (perennial grasses, legumes), ignoring and noncompliance with crop rotations. Insufficiently conducted selection of crops in a crop rotation is a frequent reason for reduced productivity and soil fertility. In these conditions, it is quite important to develop the structure of sown areas and crop rotation system for each landowner, regardless of the size of the land. It should be considered that in terms of market relations and private land ownership, the previously used structure of sown areas requires significant changes.

On the one hand, the right of inheritance to land should promote a careful attitude to it, but on the other - market relations create conditions for the activation of profits, without worrying about measures to protect soils from degradation. Last time, in practice, such phenomena have been observed when due attention is not paid to the correct selection of fore crops for the placement of highly profitable crops, including winter wheat, soybeans, etc.

Climate change has a significant impact on agricultural productivity, including significant fluctuations in rainfall, air temperatures and the devastating effects of drought. Therefore, under such conditions, agrarian science must develop and introduce into production agricultural systems on the irrigated lands, which would be adapted to the adverse effects of climate change at the global and regional scales. The use of scientifically based biologically optimal irrigation regimes developed at the Institute of Irrigated Agriculture of NAAS allows increasing the yield of winter wheat by 3.4 times, grain corn - by 4.7 ; soybeans - 3.5; alfalfa hay 2.5 times (Fig. 1). Standardization of irrigation water and other agricultural resources allows obtaining the maximum net profit and reducing anthropogenic pressure on the irrigated soils.

It should be mentioned that the negative environmental manifestations are aggravated by project errors of unbalanced general irrigation of all suitable lands of vulnerable Steppe ecosystems, noncompliance with scientifically sound systems of agriculture, imperfect techniques and technology of tillage and agricultural production, application of insufficient amount of organic fertilizers and ameliorants, low level of scientific and technical exploitation of melioration systems, ignoring the measures for environmental safety, general melioration, combating erosion and other measures in order to achieve current shortterm economic advantages. 


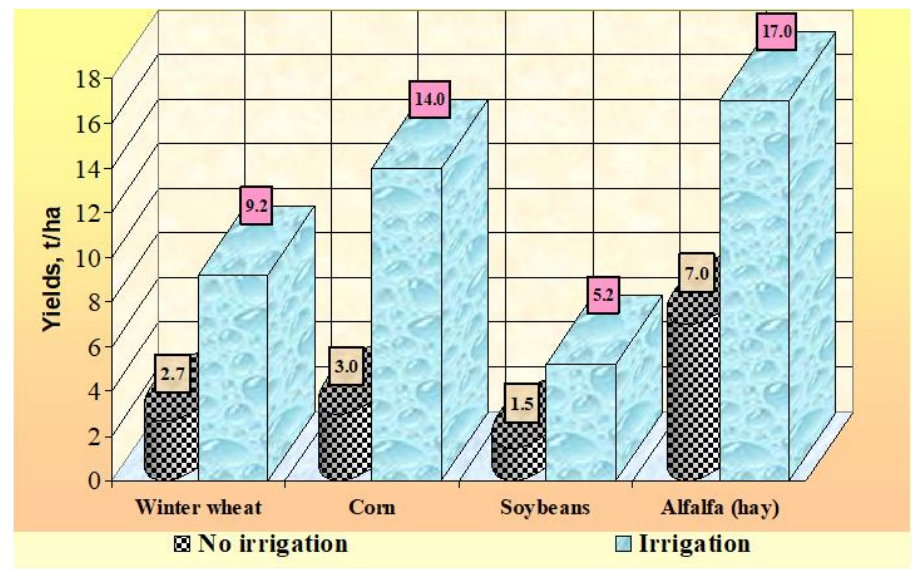

Fig. 1. Irrigation efficiency in the conditions of the South of Ukraine under the cultivation of major crops (according to the data of the Institute of Irrigated Agriculture of NAAS averaged for the period of 2015-2019)

In Kherson oblast, the area of irrigated land is about 426.3 thousand hectares, which is $21.6 \%$ of the total area of agricultural land, including rice systems occupying 16.3 thousand hectares. There is a significant dynamics of increasing the area of drip irrigation systems, which exceed 18.4 thousand hectares. However, currently 14.8 percent of the total irrigated land is strongly affected by erosion, $1.5 \%$ is udic, and more than $4 \%$ are saline, alkaline, or at risk of secondary salinization due to the rising groundwater levels and their mineralization.

The quality of irrigation water determines the water-salt regimes of the soil and, consequently, the main properties and fertility of the irrigated soils. Monitoring and management of irrigation water quality is a fundamental task of irrigation water supply, solving which will preserve and increase soil fertility of meliorated agroecosystems. Assessing the quality of irrigation water, it should be taken into account that within Kherson oblast the supply for irrigation of crops is provided from the Main Kakhovka Canal to the area of 243.1 thousand hectares, North-Crimean canal for 101.7 thousand hectares and Inhulets irrigation system for about 18.2 thousand ha. Local irrigation with unstable water quality indices provides water supply on an area of about 41.8 thousand hectares. The water of the Dnipro River belongs to the hydrocarbonatecalcium II class water by the hazard of secondary leaching and 
alkalinization. Its belonging to the "limited suitable" group indicates the need for a system of measures to prevent soil degradation.

Irrigation water of the IIS is characterized by significant seasonal fluctuations in quality indices. It is estimated as moderately mineralized, with average mineralization values of $1.5 \mathrm{~g} / \mathrm{dm}^{3}$ and amplitude of variation from 1.3 to $1.7 \mathrm{~g} / \mathrm{dm}^{3}$, chloride-sulfate and magnesium-sodium class. In general, the water quality of the Ingulets irrigation system in the period of 2018-2019 corresponded to the second quality class.

Insufficiently controlled at present systems of territorial and sectoral irrigated water consumption, which are based on the use of underground sources, in terms of environmental parameters must meet the requirements of environmentally friendly irrigation and the possibility of restoring water resources. The formation of ecologically sustainable territorial meliorated ecosystems while simultaneous preservation of the volume and quality of water resources requires a combination of the measures for restoration and maintenance of the integrity of water systems, the development of water protection infrastructure and rational use of resource potential of the zone.

Natural increase of anthropogenic load on meliorated agroecosystems, decrease in the general level of safety because of the deterioration of basic funds considerably increase the degree of technological and ecological risk of agricultural enterprises. Environmental threats are also possible due to the flaws in organization, control, and violation of production process.

The dynamics of agrochemical properties of the soils during irrigation testifies about polysemantic time dynamics of fertility and a significant impact of other constituents of the system of agriculture. Changes in the soil absorption complex are more significant. Without chemical melioration measures, irrigation of soils, especially with waters of unfavorable chemical composition, can cause different degrees of alkalinization with sodium and magnesium. With long-term irrigation without adequate systematic measures for fertility reproduction, dehumification and its migration, reduction of mobile phosphorus, exchangeable potassium and nitrification nitrogen are observed.

According to our generalizations, the main environmental risks due to the irrigation in Kherson oblast are:

- disturbance of water balance and hydrological regime of the large arrays of poorly drained areas;

- groundwater level rise, development of flooding processes and secondary irrigation hygromorphism; 
- development of the processes of primary and secondary salinization and alkalinization of the irrigated lands and adjacent territories;

- transformation of initial agrophysical properties of the soils, their compaction, change of microaggregate composition, reduction of number of water-resistant aggregates, destructuring, crusting, etc.;

- soil degradation related to water erosion processes;

- changes in soil microflora and disturbances of biological activity;

- contamination of the lands with heavy metals, radionuclides and other substances of anthropogenic origin;

- change in agrochemical properties of the soil.

Important problems at the state level are the need for technical reequipment and modernization of the irrigation systems to ensure their proper functioning in accordance with environmental standards, automation of the operational management of hydraulic structures and meliorative network. The complexity and severity of current environmental problems, and the associated decline in the productivity of agricultural landscapes, require the introduction in the regions of irrigation of a new ecological and economic model of the irrigated land use, which requires financial support and appropriate legislation.

\section{CONCLUSIONS}

Given the regional climate change in the Steppe zone of Ukraine, it is necessary to expand the directions, the program of research on the adaptation of the system of agriculture to the new agro-ecological situation, which includes: creation of new varieties and hybrids of crops with optimal parameters of adaptation to arid conditions and regional climate change; reduction of the share of plowed agricultural lands and increase in the areas with the use of agro-ameliorative measures; continuous investigation of the soil formation processes, development of the measures for preservation of the soil fertility and prevention of its degradation; restoration and construction of new irrigation systems and development of irrigated agriculture as a guarantor of a stable crop yield, effective development of the agricultural sector and rural areas in the area of irrigation. In order to increase the irrigation efficiency and reduce environmental load on the environment it is necessary to: strengthen research work on the adaptation of agricultural systems on the irrigated lands to modern climatic conditions, which are formed under the influence of global warming; to develop and implement in agricultural production innovative resource-saving, environmentally friendly technologies and anti-erosion measures, which are based on the 
principles of water conservation and a set of agricultural measures for moisture accumulation in the soil; to develop and implement innovative irrigation technologies (micro-sprinkling, subsurface irrigation), modern GIS-technologies, to create and implement special computer programs, to provide for introduction of the newest methods of the modeling of production processes in agroecosystems.

\section{SUMMARY}

The main task of crop production and agriculture in Ukraine was and remains the creation of the necessary conditions for sustainable agriculture based on intensive use of natural and agronomic resources, preservation and increase of soil fertility. In the implementation of this task, the techniques that promote efficient land use and ensure the ecological balance of the environment are important.

Climate change has a significant impact on agricultural productivity, including significant fluctuations in rainfall, air temperatures and the devastating effects of drought. Therefore, under such conditions, agrarian science must develop and introduce into production agricultural systems on the irrigated lands, which would be adapted to the adverse effects of climate change at the global and regional scales. The use of scientifically based biologically optimal irrigation regimes developed at the Institute of Irrigated Agriculture of NAAS allows increasing the yield of winter wheat by 3.4 times, grain corn - by 4.7 ; soybeans - 3.5; alfalfa hay 2.5 times. Standardization of irrigation water and other agricultural resources allows obtaining the maximum net profit and reducing anthropogenic pressure on the irrigated soils.

Given the regional climate change in the Steppe zone of Ukraine, it is necessary to expand the directions, the program of research on the adaptation of the system of agriculture to the new agro-ecological situation, which includes: creation of new varieties and hybrids of crops with optimal parameters of adaptation to arid conditions and regional climate change; reduction of the share of plowed agricultural lands and increase in the areas with the use of agro-ameliorative measures; continuous investigation of the soil formation processes, development of the measures for preservation of the soil fertility and prevention of its degradation; restoration and construction of new irrigation systems and development of irrigated agriculture as a guarantor of a stable crop yield, effective development of the agricultural sector and rural areas in the area of irrigation. 


\section{References}

1. Вожегова Р. А., Малярчук М. П., Дробітько А. В. та ін. Наукове обгрунтування напрямів адаптації систем землеробства до кліматичних змін та забезпечення продовольчої безпеки. Наукові основи адаптації систем землеробства до змін клімату в Південному Cmепу України : колект. моногр. / за ред. чл.-кор. НААН Вожегової Р. А. Херсон : ОЛДІ-ПЛЮС, 2018. С. 8-39.

2. Гадзало Я. М., Вожегова Р. А., Коковіхін С. В., Біляєва І. М., Дробітько А. В. Наукове обгрунтування технологій вирощування кукурудзи на зрошуваних землях із урахуванням гідротермічних чинників і змін клімату. Зрошуване землеробство. Херсон, 2020. Вип. 73. С. 21-26.

3. Жовтоног О. I., Кириєнко О. І., Шостак I. К. Алгоритм планування зрошення 3 використанням геоінформаційних технологій для системи точного землеробства. Меліорація $i$ водне господарство. 2004. Вип. 91. С. 33-41.

4. Зубець М. В. Наукові основи агропромислового виробництва в зоні Степу України. Київ : Аграрна наука, 2004. С. 359-363.

5. Жуйков Г. Є., Димов О. М. Нормативи витрат матеріальнотехнічних ресурсів при вирощуванні основних зернових культур : науково-методичний посібник. Херсон : Айлант, 2004. 20 с.

6. Іващенко О. О., Рудник-Іващенко О. І. Напрями адаптації аграрного виробництва до змін клімату. Вісник аграрної науки. 2011. № 8. C. 10-12.

7. Коваленко А. М., Коковіхін С. В., Нікішов О. О. Фотосинтетична діяльність та насіннєва продуктивність пшениці озимої залежно від захисту рослин та мікродобрив в умовах Півдня України. Зрошуване землеробство : міжвідомчий тематичний збірник наукових праць. Херсон : Грінь Д.С., 2017. Вип. 67. С. 131-134.

8. Коковіхін С. В. Моделювання агротехнологічних параметрів системи зрошуваного землеробства 3 урахуванням показників гідромодулю системи та біологічних потреб культур у короткоротаційних сівозмінах Півдня України. Стан і перспективи впровадження ресурсоощадних, енергозберігаючих технологій вирошування сільськогосподарських культур : матеріали II Міжнародної науково-практичної конференції (15-16 листопада 2017 р.). Дніпро : ДДАЕУ, 2017. С. 60-62.

9. Сайко В. Ф. Наукові основи землеробства в контексті змін клімату. Вісник аграрної науки. 2008. № 11. С. 5-10. 
10. Тараріко Ю. О. Розробка грунтозахисних ресурсо- та енергозберігаючих систем ведення сільськогосподарського виробництва 3 використанням комп'ютерного програмного комплексу. Київ : Нора-Друк, 2002. 122 с.

11.Полупан М. І., Соловей В. Б., Величко В. А. Класифікація грунтів України. Київ : Аграрна наука, 2005. С. 144-156.

12. Третяк А. М., Бобміндра Д. І. Земельні ресурси України та їх використання. Київ, 2003. 144 с.

13. Ушкаренко В. О., Андрусенко І. І., Пилипенко Ю. В. Екологізація землеробства і природокористування в Степу України. Таврійський науковий вісник. Херсон : Айлант, 2005. Вип. 38. С. 168-175.

14. Ушкаренко В. О., Вожегова Р. А., Голобородько С. П., Коковіхін С. В. Статистичний аналіз результатів польових дослідів у землеробстві : монографія. Херсон : Айлант, 2013. 403 с.

15.Ничипорович А. А. Фотосинтетическая деятельность растений в посевах. Москва : АН СССР, 1961. 133 с.

16. Агрокліматичні ресурси півдня України та їх раціональне використання: монографія / Лимар А. О., Лимар В. А., Коковіхін С. В. Домарацький Є. О. Херсон : Грінь Д.С., 2015. 246 с.

Information about the author: Vozhehova Raisa Anatoliivna, Doctor of Agricultural Sciences, Professor, Director Institute of Irrigated Agriculture of National Academy of Agrarian Sciences of Ukraine Naddnipryanske sett., 73483, Kherson region, Ukraine 